\title{
KEEFEKTIFAN MODEL PEMBELAJARAN CREATIVE PROBLEM SOLVING (CPS) TERHADAP PRESTASI BELAJAR MATEMATIKA SMP NEGERI 3 NGABANG
}

\author{
Jeliana Intan Permata, M.Pd ${ }^{1)}$, \\ ${ }^{1}$ Program Studi Pendidikan Matematika, STKIP Pamane Talino \\ email: jelianaintan@gmail.com
}

\begin{abstract}
Abstrak
Pembelajaran matematika di SMP Negeri 3 Ngabang masih belum optimal. Permasalahan yang dialami adalah kurangnya keterlibatan siswa dalam proses pembelajaran. hal ini berkaitan pula dengan pemilihan model pembelajaran yang kurang tepat. Hal ini berpengaruh terhadap rendahnya prestasi belajar siswa. Tujuan penelitian ini adalah untuk mengetahui kefektifan model pembelajaran Creative Problem Solving (CPS) terhadap prestasi belajar matematika siswa. Metode penelitian yang digunakan adalah metode kuantitatif dengan studi komparasai. Uji prasyarat yang dilakukan uji normalitas dan uji homogenitas. Uji hipotesis menggunakan uji t. Hasil penelitian menunjukan bahwa model pembelajaran CPS efektif terhadap prestasi belajar matematika dibandingkan model pembelajaran langsung. Hasil analisis data akhir menunjukkan proporsi peserta didik kelas eksperimen telah mencapai KKM individual dengan hasil $t_{\text {hitung }}>t_{\text {tabel }}$ atau 5,64>1,68 Berdasarkan uji beda rata-rata diperoleh thitung $=1,751>1,67=$ ttabel dan dengan $\alpha=5 \%$.
\end{abstract}

Kata Kunci: pembelajaran, prestasi belajar.

\begin{abstract}
Mathematics learning in SMP Negeri 3 Ngabang is still not optimal. The problem experienced is a lack of student involvement in the learning process. this is also related to the selection of inappropriate learning models. This affects the low student achievement. In The purpose of this study was to determine the effectiveness of the Creative Problem Solving (CPS) learning model on student mathematics learning achievement. The research method used is a quantitative method with comparative studies. The prerequisite test carried out normality test and homogeneity test. Hypothesis testing using $t$ test. The results of the study show that the model CPS learning is effective against mathematics learning achievement compared to direct learning models. The results of the final data analysis showed the proportion of experimental class students had reached individual KKM with the results of $t_{\text {count }}>t_{\text {table }}$ or $5.64>1.68$ Based on the average difference test obtained $t_{\text {count }}=1.751>1.67=$ $t_{\text {table }}$ and $=5 \%$.
\end{abstract}

Keywords: learning, learning achievement.

\section{Pendahuluan}

Pembelajaran matematika sejauh ini masih dipandang sebagai momok yang menakutkan bagi siswa. Hal ini dikarenakan matematika mempunyai objek; yaitu fakta, konsep, dan prinsip yang abstrak sehingga sulit dimengerti. Kartini (2009: 367) menyatakan model matematika pada dasarnya juga suatu representasi ideal terhadap sesuatu yang dinyatakan dalam bentuk simbol dan ekspresi matematika. 
Kesulitan yang dihadapi siswa dalam pembelajaran matematika berdampak pada rendahnya prestasi belajar siswa. Prestasi belajar menurut Hamdani (2011:138) adalah hasil pengukuran dari penilaian usaha belajar yang dinyatakan dalam bentuk simbol, huruf maupun kalimat yang menceritakan hasil yang sudah dicapai oleh setiap anak pada periode tertentu.

Rendahnya hasil belajar matematika siswa diduga disebabkan oleh kesulitan memahami matematika. Hal ini tidaklah mengherankan karena selama ini pembelajaran matematika masih bersifat konvensional. Guru lebih banyak mendominasi dalam proses pembelajaran.

Pembelajaran yang berlangsung di sekolah sebagian besar membuat siswa kurang antusias menerima materi, siswa lebih bersifat pasif, enggan, takut atau malu untuk mengemukakan pendapatnya. Perlu adanya inovasi dalam pemilihan model pembelajaran yang tepat untuk peningkatan prestasi belajar siswa.

Pembelajaran yang akan dilakukan dengan menekankan kepada peningkatan prestasi belajar yang dimiliki siswa, yakni model pembelajaran Creative Problem Solving (CPS). Sejalan dengan penelitian Suryani (2013) bahwa pembelajaran CPS mampu meningkatkan hasil belajar dan kreativitas siswa.

Pembelajaran CPS memberikan kesempatan kepada siswa untuk bekerja sama dalam menyelesaikan permasalahan matematika. Siswa diajak untuk beproses berpikir kreatif dalam penyelesaian soal-soal yang diberikan oleh guru.

Kesempatan penyelesaian masalah secara kreatif berkaitan dengan hasil belajar siswa. Hasil belajar merupakan berbagai kemampuan yang dimiliki siswa setelah menerima pengalaman belajarnya (Sudjana, 2009: 22). Hasil belajar dalam penelitian ini dilihat dari aspek kognitif yakni prestasi belajar matematika siswa.

Model pembelajaran $C P S$ adalah suatu model pembelajaran yang melakukan pemusatan pada pengajaran dan keterampilan pemecahan masalah, yang diikuti dengan penguatan keterampilan (Pepkin, 2000: 13). Dalam pembelajaran ini, peserta didik dapat melakukan keterampilan memecahkan masalah untuk memilih dan mengembangkan tanggapannya.

Langkah-langkah pembelajran $C P S$ sebagai metode untuk menyelesaikan masalah secara kreatif terdiri dari 6 struktur yakni objective finding, idea finding, solution finding, dan acceptence finding, yang secara operasional termuat dalam tabel sintak proses CPS berdasarkan kriteria OFPISA model Osborn-Parnes (Huda 2013: 298). Langkah ini diharapkan mampu meningkatkan prestasi belajar siswa. Siswa dilatih untuk berpikir kreatif dalam penyelesaian maslah matematika.

Penggunaan model pembelajaran yang tepat dapat memberikan pengaruh yang baik dalam proses belajar mengajar. Proses belajar mengajar yang baik diharapkan memberi hasil belajar yang baik pula. Hasil belajar yang dimaksud adalah prestasi belajar yang dimiliki siswa yang merupakan hasil dari poses belajar yang baik.

Peningkatan prestasi belajar siswa dapat dilakukan tidak hanya dengan cara menghafal tanpa dipikir, akan tetapi keterampilan memecahkan masalah juga dapat memperluas proses berpikir. Prestasi belajar menurut Hamdani (2011:138) adalah hasil pengukuran dari penilaian usaha belajar yang dinyatakan dalam bentuk simbol, huruf maupun kalimat yang menceritakan hasil yang sudah dicapai oleh setiap anak pada periode tertentu.

Kenyataannya model pembelajaran yang digunakan masih kurang tepat. Siswa merasa kurang termotivasi dan menganggap bahwa pelajaran matematika sulit. Alternatif model pembelajaran yang dapat digunakan adalah Creative Problem Solving (CPS). Model CPS merupakan suatu model pembelajaran yang melakukan pemusatan pada pengajaran dan keterampilan pemecahan masalah yang diikuti dengan penguatan keterampilan (Pepkin, 2004:1) 
Penggunaan model CPS ini diharapkan peserta didik dapat melakukan keterampilan memecahkan masalah untuk memilih dan mengembangkan tanggapannya secara kreatif ketika dihadapkan dengan suatu masalah.

Kelebihan model pembelajaran CPS adalah siswa diajak untuk berpikir kreatif dalam pemecahan masalah. Pemecahan masalah dalam pembelajaran tidak hanya dilakukan dalam satu cara, tetapi ada alternatif dari penyelesaian masalah.

Sanjaya (Asikin, 2008: 40) menyebutkan keunggulan-keunggulan tersebut antara lain bahwa pemecahan masalah: merupakan teknik yang cukup bagus untuk memahami isi pelajaran; dapat menantang kemampuan siswa serta memberikan kepuasan untuk menemukan; dapat meningkatkan aktivitas pembelajaran siswa; dapat membantu siswa bagaimana mentransfer pengetahuan mereka untuk memahami masalah dalam kehidupan nyata; dapat membantu siswa untuk mengembangkan pengetahuan barunya dan bertanggung jawab dalam pembelajaran yang mereka lakukan.

Model pembelajaran $C P S$ yang diterapkan diharapkan efektif terhadap prestasi belajar siswa. Ketuntasan belajar siswa yang mencapai ketuntasan KKM individual lebih dari $70 \%$. Model pembelajaran $C P S$ efektif terhadap prestasi belajar siswa.

\section{Metode Penelitian}

Penelitian ini dilaksanakan di SMP Negeri 3 Ngabang. Populasi dari penelitian ini adalah siswa kelas VIII. Sampel dalam penelitian ini adalah kelas VIII A dan VIII B. Pengambilan sampel dilakukan dengan teknik purpossive random sampling. Teknik pengumpulan data menggunakan tes prestasi belajar siswa pada materi kubus dan balok. Tes ini berupa 30 soal pilihan ganda yang terlebih dahulu diujicobakan untuk melihat kelayakan tes sebelum digunakan.

Uji kelayakan instrumen tes yang pertama adalah uji validitas isi yang diuji oleh 2 orang validator, terdiri dari satu orang guru matematika SMP Negeri 3 Ngabang dan satu orang dosen Pendidikan Matematika. Selanjutnya, adalah uji reliabilitas menggunakan rumus Alpha dengan indeks $\mathrm{r} 11 \geq 0,80$. Tingkat kesukaran yang digunakan yaitu pada tingkat sedang antara $0,31-0,70$. Sedangkan untuk daya beda antara 0,41-0,70 berkeriteria baik.

Variabel dalam penelitian ini adalah prestasi belajar siswa. Teknik analisis data yang dilakukan adalah Uji ketuntasan individual menggunakan uji proporsi satu pihak dan uji hipotesis menggunakan uji t. Uji prasayarat penelitian sebelum pengujian hipotesis yang dilakukan adalah uji normalitas dan homogenitas. Hasil uji normalitas menggunakan uji Kolmogrov Smirnov. Uji homogenitas menggunakan uji Bartlett.

\section{Hasil Dan Pembahasan}

Instrumen dalam penelitian ini sebelum digunakan diuji terlebih dahulu pada siswa di SMP Negeri 3 Ngabang. Hasil uji coba instrumen adalah yang pertama pada uji validitas isi. Validasi dilakukan oleh dua orang ahli matematika dengan hasil validator pertama diperoleh bahwa instrumen uji coba tes prestasi belajar masih ada yang tidak sesuai dengan kompetensi dasar dan harus diperbaiki. Hasil validasi oleh validator kedua adalah keterurutan dalam pilihan jawaban harus diperbaiki dan pertanyaan dalam soal uji coba harus diurutkan sesuai dengan urutan Kompetensi dasar.

Uji reliabilitas menggunakan rumus Alpha dengan indeks $r_{11} \geq 0,80$ maka instrumen penelitian reliabel dan dapat digunakan. Tingkat kesukaran yang digunakan yaitu pada tingkat sedang antara 0,31-0,70 dengan rincian sebagai berikut: 
Tabel 1. Tingkat Kesukaran

\begin{tabular}{|c|c|}
\hline No Soal & Kriteria \\
\hline $2,3,5,7,25$ & Mudah \\
\hline $1,4,6,8,10,11,12,13,14,15,16,18$, & \\
$19,20,21,22,23,24,26,28,29,30$ & Sedang \\
\hline $9,27,1,17$ & Sukar \\
\hline
\end{tabular}

Tabel 2. Daya Pembeeda

\begin{tabular}{|c|c|}
\hline No Soal & Kriteria \\
\hline 2,3 & Jelek \\
\hline $5,7,25,30$ & Sedang \\
\hline $\begin{array}{c}1,4,6,8,10,11,12,13,14,15,16,18, \\
19,20,21,22,23,24,26,28,29\end{array}$ & Baik \\
\hline
\end{tabular}

Soal yang digunakan berdasarkan uji kelayakan instrumen berjumlah 20 soal. Dengan nomor soal 1, 4,6,8, 10, 11, 12, 13, 14, 15, 16, 18, 19,20,21,22,23,24, 26, $28,29$.

Uji prasyarat dalam pengujian hiptesis adalah data berdistribusi normal dan homgen. Uji normalitas dalam penelitian ini menggunakan uji kolmogorov smirnov dengan hasil uji menunjukkan data bersistribusi normal dengan dengan nilai signifikan $=0.054=5,4 \%>5 \%$.

Uji homogenitasa dalam penelitian ini menggunakan uji Bartlet. Hasil uji pada uji homogenitas diperoleh $\mathrm{x}^{2}$ itung $=0,300<\mathrm{x}^{2}$ tabel $=3,841$ sehingga dapat disimpulkan sampel berasal dari populasi

yang homogen. Berdasarkan hasil uji prasyarat dapat disimpulkan bahwa data bersitribusi normal dan homgen. Syarat untuk pengujian hiptesis telah dipenuhi.

Uji hipotesis dalam penelitian ini menggunakan uji $t$ diperoleh $t_{\text {hitung }}=1,751>1,67=t_{\text {tabel }}$ dan dengan $\boldsymbol{\omega}=5 \%$. Disimpulkan bahwa diterima yang berarti model pembelajaran Creative Problem Soving (CPS) lebih efektif dibandingkan dengan penggunaan model pembelajaran langsung terhadap prestasi belajar SMP Negeri 3 Ngabang.

Uji proporsi satu pihak hasil analisis data akhir menunjukkan proporsi peserta didik kelas eksperimen telah mencapai KKM individual dengan hasil $t_{\text {hitung }}>t_{\text {tabe }} 1$ atau 5,64>1,68. Disimpulkan bahwa kesimpulan yang diperoleh adalah rata-rata nilai Tes Prestasi belajar siswa yang pembelajarannya menggunakan pembelajaran $C P S$ telah mencapai $\mathrm{KKM}=70$.

Pembelajaran $C P S$ efektif dalam peningkatan prestasi belajar siswa. Pembajaran $C P S$ yang diterapkan mampu mengasah kemampuan pemecahan masalah. Pemecahan masalah dalam matematika merupakan kompetensi yang wajib dimiliki oleh siswa.

Poblem solving merupakan elemen penting dalam pembelajaran matematika yang berkaitan dengan prestasi belajar siswa (Pepkin, 2000:1). Pembelajaran CPS efektif dalam meningkatkan prestasi belajar siswa karena memberi ruang kepada siswa untuk berpikir kreatif dalam pemecahan masalah matematika. pemikiran kreatif inilah yang membantu siswa dalam proses penyelesaian masalah. Trefingger (2005) mengajar dan mengaplikasikan CPS memberi dampak pada prestasi belajar siswa.

Pembelajaran CPS efektif terhadap peningkatan prestasi belajar dikarenakan proses pemecahan masalah yng diterapkan dalam pembelajaran mengasah cara berpikir kreatif siswa. Hal ini sejalan dengan hasil penelitian Manurung (2017); Pepkin (2000); Siswono 
Keefektifan Model Pembelajaran Creative Problem Solving (CPS) Terhadap Prestasi Belajar Matematika Smp Negeri 3 Ngabang

Jeliana Intan Permata, M.Pd ${ }^{1}$,

(2011) bahwa proses pembelajaran CPS meningkatkan proses berpikir kreatif dalam pemecahan masalah matematika. proses berpikir kreatif ini mempengaruhi pula pada prestasi belajar siswa dalam pembelajaran matematika. siswa menjadi lebih terampil dan memiliki kemampuan untuk berpikir kreatif dalam pemecahan masalah.

\section{Kesimpulan}

Pembelajaran $C P S$ efektif terhadap prestasi belajar siswa dibandingkan dengan model pembelajaran langsung. Hal ini didukung dengan hasil penelitian bahwa pembelajaran $C P S$ efektif dibandingkan pembelajaran langsung terhadap prestasi belajar matematika siswa SMP Negeri 3 Ngabang. Uji proporsi satu pihak menyimpulkan bahwa proporsi peserta didik kelas eksperimen telah mencapai KKM individual. Siswa dengan model pembelajaran CPS memperoleh nilai rata-rata 75,78 dan dengan model pembelajaran langsung nilai rata-rata siswa 56. Berdasarkan pengujian hipotesis dengan diperoleh thitung $=1,751>1,67=$ ttabel dan dengan $\boldsymbol{a}=5 \%$. Pembelajaran CPS menekankan pada proses berpikir kreatif dalam pemecahan masalah. Siswa mampu berpikir kreatif sehingga pemecahan masalah matematika menjadi mudah dicari solusinya. Hal ini berdampak pula pada prestasi belajar siswa.

\section{Referensi}

Hamdani. 2011. Strategi Belajar Mengajar. Bandung: Pustaka Setia.

Huda, 2013. Model-model Pengajaran dan Pembelajaran. Yogyakarta: Pustaka Pelajar.

Kartini, 2009. Peranan Representasi dalam Pembelajaran Matematika. Jurusan Pendidikan Matematika FMIPA UNY. Diakses 1 Oktober 2018. http://eprints.uny.ac.id/7036/.

Manurung. 2017. Penerapan Model Pembelajaran Creative Problem Solving Dalam Meningkatkan Kemampuan Berpikir Kreatif Matematika Pada Siswa Sekolah Menengah Pertama (SMP) Al Hidayah Medan. Journal Mathematic Education. https://www.researchgate.net/publication/321833110

Pepkin, L. Kasen. 2000. Creative Problem Solving In Math. Tersedia di http://www,mathematic.transdigit.com/index.php/category/mathematic-info/

Sanjaya, W. 2006. Strategi Pembelajaran. Jakarta: Kencana Prenada Media Group.

Siswono, T.Y.E. 2011. Level of Students' Creative Thinking in Classroom Mathematics. Educational Research and Review, 6, (7), 548-553.

Sudjana, N., 2009. Penilaian Hasil Proses Belajar Mengajar. Bandung: PT. Remaja Rosdakarya.

Suryani, A., Sugiarto, Alamsyah. 2013. Keefektifan Creative Problem Solving Terhadap Hasil Belajar Peserta Didik Mts Miftakhul Khoirot. Unnes Journal of Mathematics Education. http://journal.unnes.ac.id/sju/index.php/ujme

Treffinger, D.J., S.G. Isaksen, K.B. Dorval. 2005. Creative Problem Solving (CPS Version $6.1 \mathrm{TM})$ A Colntemporary Framework for Managing Change. Diakses pada 23 Oktober 2015 (http://www.creativelearning.com/PDF/CPSVersion61. pdf) 